\title{
Arbuscular Mycorrhizal Fungal Community Composition in Carludovica palmata, Costus scaber and Euterpe precatoria from Weathered Oil Ponds in the Ecuadorian Amazon
}

\author{
Mónica Garcés-Ruiz ${ }^{1,2}$, Carolina Senés-Guerrero ${ }^{3}$, Stéphane Declerck ${ }^{1 *}$ and \\ Sylvie Cranenbrouck ${ }^{1,4}$ \\ ${ }^{1}$ Laboratory of Mycology, Earth and Life Institute, Université catholique de Louvain, Louvain-la-Neuve, Belgium, ${ }^{2}$ Laboratorio \\ de Micología, Facultad de Ciencias Exactas y Naturales, Pontificia Universidad Católica del Ecuador, Quito, Ecuador, \\ ${ }^{3}$ Escuela de Ingeniería y Ciencias, Tecnologico de Monterrey, Monterrey, Mexico, ${ }^{4}$ Laboratory of Mycology, Mycothèque de \\ I'Université catholique de Louvain (BCCM/MUCL ${ }^{1}$ ), Earth and Life Institute, Université catholique de Louvain, \\ Louvain-la-Neuve, Belgium
}

OPEN ACCESS

Edited by:

Anna Maria Pirttilä,

University of Oulu, Finland

Reviewed by:

Marcela Claudia Pagano,

Universidade Federal de Minas

Gerais, Brazil

Roberta Fulthorpe,

University of Toronto Scarborough,

Canada

*Correspondence:

Stéphane Declerck

stephan.declerck@uclouvain.be

Specialty section: This article was submitted to Fungi and Their Interactions,

a section of the journal

Frontiers in Microbiology

Received: 03 August 2017

Accepted: 18 October 2017

Published: 07 November 2017

Citation:

Garcés-Ruiz M, Senés-Guerrero C,

Declerck S and Cranenbrouck S (2017) Arbuscular Mycorrhizal Fungal Community Composition

in Carludovica palmata, Costus scaber and Euterpe precatoria from Weathered Oil Ponds

in the Ecuadorian Amazon.

Front. Microbiol. 8:2134.

doi: 10.3389/fmicb.2017.02134
Arbuscular mycorrhizal fungi (AMF) are ubiquitous to most natural and anthropized ecosystems, and are often found in polluted environments. However, their occurrence and community composition in highly weathered petroleum-polluted soils has been infrequently reported. In the present study, two ponds of weathered crude oil and their surrounding soil from the Charapa field in the Amazon region of Ecuador were selected and root colonization by AMF of their native plants investigated. The AMF community was further analyzed in three selected plant species (i.e., Carludovica palmata, Costus scaber and Euterpe precatoria) present in the two ponds and the surrounding soil. A fragment covering partial SSU, the whole ITS and partial LSU rDNA region was amplified (i.e., $1.5 \mathrm{~kb}$ ), cloned and sequenced from the roots of each host species. AMF root colonization exceeded $56 \%$ in all plant species examined and no significant difference was observed between sites or plants. For AMF community analysis, a total of 138 AMF sequences were obtained and sorted into 32 OTUs based on clustering (threshold $\geq 97 \%$ ) by OPTSIL. The found OTUs belonged to the genera Rhizophagus (22\%), Glomus (31\%), Acaulospora (25\%) and Archaeospora (22\%). Glomus and Archaeospora were always present regardless of the plant species or the site. Acaulospora was found in the three plant species and in the two ponds while Rhizophagus was revealed only in the surrounding soil in one plant species (Euterpe precatoria). Our study contributed to the molecular community composition of AMF and revealed an unexpected high presence of four AMF genera which have established a symbiosis with roots of native plants from the Amazon forest under high polluted soil conditions.

Keywords: arbuscular mycorrhizal fungi, weathered crude oil pond, symbiosis, Amazon forest, Ecuador, community composition

\footnotetext{
${ }^{1}$ Part of the Belgian Coordinated Collections of Micro-organisms (BCCM).
} 


\section{INTRODUCTION}

Ecuador is considered as a biodiversity hot spot, especially the Amazonian region which is emblematic for its rich and diverse flora and fauna. Despite of its ecological importance, the seventies marked the initiation of oil exploration and exploitation of the Amazonian forest. This led to a series of environmental disasters such as the contamination of rivers and groundwater, deforestation, precarious waste storage or weathered crude oil ponds (Armstrong and Vallejo, 1997).

Crude oil is a mixture of many compounds, such as alkanes, aromatics, asphaltenes and resins (Robertson et al., 2007). The alkanes and the polyaromatic hydrocarbons are the most easily biodegradable, by contrast to the asphaltenes and resins which are more resistant (Singh, 2006). The physicochemical composition affected by temperature, sun radiation, humidity and biological action left weathered crude oil accrued, eventually turning them in environmental liabilities (Singh, 2006).

The lack of environmental laws in Ecuador until 1990 (Armstrong and Vallejo, 1997) left around 2550 environmental liabilities caused by the oil industry (Ministerio del Ambiente de Ecuador [MAE], 2015). PetroAmazonas EP, an Ecuadorian public enterprise engaged in the exploration and extraction of oil reserves has concentrated its activities in production fields in the Amazon basin. Moreover, it is committed to the recovery of some environmental liabilities. Some of the weathered crude oil ponds are between 30 to 40 years old, despite of the intensive soil contamination, gradually these have been naturally recolonized by plants from the area.

The environmental consequences of weathered crude oil have mostly been measured in terms of flora and fauna, while microbial diversity has been most often ignored, even though microbes provide many ecological services.

Arbuscular mycorrhizal fungi (AMF) are soil inhabitants forming associations with the vast majority of plant species. They play key roles in soil processes (e.g., soil structure, biogeochemical cycles) (Rillig, 2004; Simard and Austin, 2010), help plants to acquire nutrients in exchange for carbohydrates (Abbott and Lumley, 2014) and protect them from biotic (Smith and Read, 2008) and abiotic (Plouznikoff et al., 2016) stresses. For instance, Cabello (1999) observed an increase in plant height and shoot biomass as well as $\mathrm{P}$ and $\mathrm{Zn}$ content in AMF-colonized Medicago sativa species grown in a hydrocarbon-polluted substrate as compared to non-colonized plants. Rajtor and PiotrowskaSeget (2016) argued that phytoremediation with AMF and/or hydrocarbon-degrading microorganisms are an effective strategy for dissipation of organic pollutants.

Arbuscular mycorrhizal fungi have been described in various biomes from temperate (Dodd, 2000) to tropical (Declerck et al., 1998; Homeier et al., 2013) and polar/boreal ecosystems (Öpik et al., 2013), under natural forests (Schüßler et al., 2015) as well as under crop cultivation systems (Senés-Guerrero et al., 2014; Buysens et al., 2016). A number of studies also reported their presence in environments polluted by heavy metals (Vallino et al., 2006; Liang et al., 2009; Gil-Cardeza et al., 2014; Wei et al., 2015; Ferrol et al., 2016) or petroleum hydrocarbons (Cabello, 1997; Hassan et al., 2014; de la Providencia et al., 2015). Although, their diversity in Ecuadorian petroleum hydrocarbons polluted soils is mostly unknown. Only one study (Villacrés et al., 2014) reported the presence of spores belonging to Glomus and Acaulospora in hydrocarbon-polluted soils from the Orellana province in the city La Joya de los Sachas (Amazon region). Species identification was done via morphological examination of spores which could highly change with age and due to the influence of different environmental stresses (Clapp et al., 1995; Bever et al., 1996; Declerck et al., 2000; Rillig et al., 2013).

Nowadays, molecular characterization is the current methodology that has reclassified a high number of AMF species (Souza, 2015). Krüger et al. (2012) developed a phylogenetic reference data for systematics and phylotaxonomy of AMF, that has been used as DNA barcode for AMF (Senés-Guerrero and Schüßler, 2016b; Wang et al., 2016). This reference dataset is an important tool to identify AMF from environmental samples. Interestingly, various surveys have been conducted on AMF diversity in industrial soils polluted by oil, using morpho-taxonomy (Cabello, 1997; Villacrés et al., 2014) and more importantly molecular tools (Hassan et al., 2014; de la Providencia et al., 2015; Iffis et al., 2016) thus increasing the accuracy of species identification. It is therefore interesting to study microbial communities associated with these plants and polluted sites, focusing in particular on AMF. Among these environmental liabilities is the Charapa field, in the province of Sucumbíos. The site is heavily contaminated with petroleum hydrocarbons. However, through the years many plants have recolonized these sites naturally.

The aim of this study was to analyze AMF root colonization in different plants species composing the ponds and surrounding soil and to determine the AMF community from three specific plants (Carludovica palmata, Costus scaber and Euterpe precatoria) present across the sites.

\section{MATERIALS AND METHODS}

\section{Sampling Location}

The sampling site was located in the Amazonian region in the Province of Sucumbíos, Ecuador, in the environmental liability known as Charapa field at 309 masl. This area corresponds to a plant community known as Lowland Evergreen Forest (Palacios et al., 1999; Pérez, unpublished).

The site has a surface of $244 \mathrm{~km}^{2}$ and contains weathered crude oil polluted ponds. Two ponds were considered for this study. Pond $1\left(76^{\circ} 48^{\prime} 57^{\prime \prime} \mathrm{W}, 00^{\circ} 11^{\prime} 49^{\prime \prime} \mathrm{S}\right)$ has a surface of $330 \mathrm{~m}^{2}$ and Pond $2\left(76^{\circ} 48^{\prime} 54^{\prime \prime} \mathrm{W}, 00^{\circ} 11^{\prime} 46^{\prime \prime} \mathrm{S}\right)$ a surface of $450 \mathrm{~m}^{2}$. The flora ecosystem was characterized by the botanist A. Pérez (unpublished). Both ponds are covered with a $10 \mathrm{~cm}$ layer of decomposed organic matter and are colonized by native plants from a secondary forest dominated by herbaceous plants and trees (Figure 1). In Pond 1, the predominant tree species are Ficus insipida (wild fig), Ficus cf. americana (West Indian laurel fig or Jamaican cherry fig), Hieronyma alchorneoides (mascarey) and Croton lechleri (dragon's blood); while the more abundant herbaceous species are Dimerocostus strobilaceus (sour cane), Carludovica palmata (Panama hat plant -palm like), Heliconia cf. 

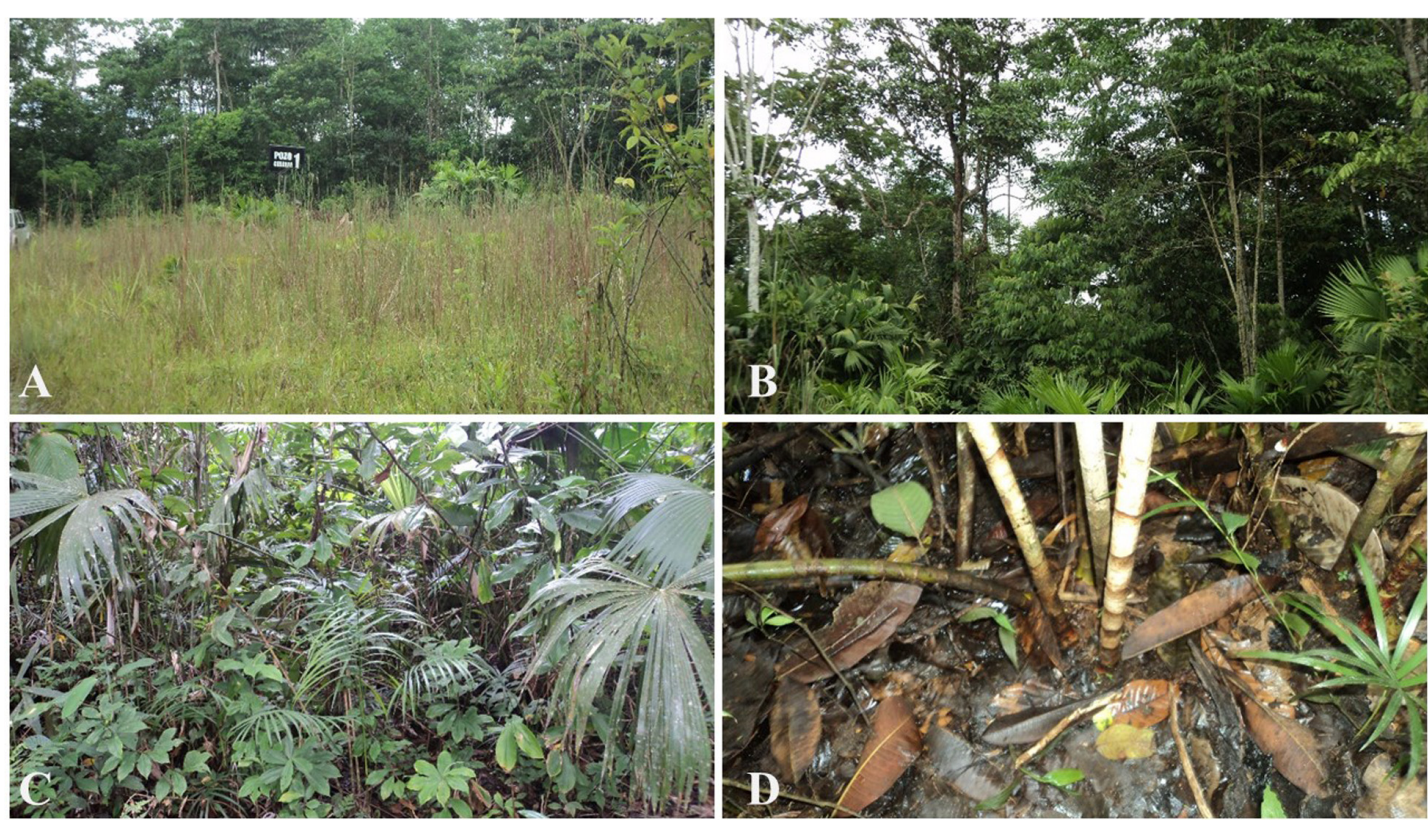

FIGURE 1 | Charapa field. Vegetation present in the ponds and surrounding soil. (A) Herbaceous plants outside the ponds. (B) Trees present inside the ponds. (C) Herbaceous plants inside the ponds. (D) Contaminated soil where plants grow.

chartacea and several species of Araceae (i.e., Euterpe precatoria Mart. - palm like). In Pond 2, the predominant tree species are Ficus insipida, Ficus cf. americana, and several species of Miconia; while the dominant herbaceous species are D. strobilaceus (sour cane) and several species of Costus (sour cane - ginger like), C. palmata, $H$. cf. chartacea and several species of Marantaceae. In the surrounding soil the predominant tree species are Ficus, Croton lechleri and Sapium glandulosum while the dominant herbaceous species are Costus scaber, Carludovica palmata, Heliconia cf. chartacea several species of Araceae, besides pasture and crop species (i.e., cassava, banana cacao) were identified.

\section{Experimental Site}

Herbaceous plants were randomly harvested from the two ponds and the surrounding soil in December 2012. Forty eight plants representing nine different species were sampled, (i.e., 21 in Ponds 1 and 2 and 6 in the surroundings) (Table 1) for root colonization evaluation. Due to the complexity of the sampling environment and the difficulties in the plant identification, three plant species (Carludovica palmata, Costus scaber, and Euterpe precatoria) found in the two ponds and surrounding soil, were further considered for AMF diversity assessment via molecular tools. For both analyses, the root samples were kept within the rhizosphere soil and dried at room temperature $\left(28-30^{\circ} \mathrm{C}\right.$, standard temperature in the Amazon region) for 4 days and stored at $4^{\circ} \mathrm{C}$. Before processing, roots were cleared from mineral and organic debris.

\section{AMF Root Colonization}

Roots were cut into pieces of $2-3 \mathrm{~cm}$ and stained into acidic-blue ink as described by Walker (2005). The percentage of total colonization (\%TC), arbuscular (\%AC) and spores/vesicles (\%VC) colonization were estimated under a dissecting microscope (Olympus BH2-RFCA, Japan) at 10x magnification according to McGonigle et al. (1990). An approximate of 100 intersections were observed per plant.

\section{DNA Extraction}

Roots from C. palmata, C. scaber and E. precatoria were selected for AMF community composition. One plant per species was selected in each site and thus a total of 9 plants were analyzed. Between 55 and $100 \mathrm{mg}$ of roots were grinded in liquid $\mathrm{N}_{2}$ with a mortar pestle to obtain a complete root disruption. The grounded material was transferred into the Lysing Matrix E tube from the FastDNA ${ }^{\circledR}$ SPIN Kit for Soil (MP Biomedicals, United States) and DNA was extracted following the manufacturer's protocol. DNA integrity was analyzed by

TABLE 1 | Number of plant species sampled by site.

\begin{tabular}{cccc}
\hline Plant species & Pond 1 & Pond 2 & $\begin{array}{c}\text { Surrounding } \\
\text { soil }\end{array}$
\end{tabular}

Monotagma sp. 1

Polybotrya sp. 2

Geonoma cf. deversa (Poit.) Kunth

Euterpe precatoria Mart.

Costus scaber Ruiz \& Pav.

Costus pulverulentus C. Presl

Costus lima var. scabremarginatus Maas

Carludovica palmata Ruiz \& Pav

Polybotrya sp. 1

$\begin{array}{lll}4 & 4 & \\ & 1 & 1 \\ 1 & 2 & \\ 7 & 4 & 2 \\ 2 & 1 & 1 \\ 1 & 2 & \\ 2 & 3 & 1 \\ 2 & 3 & 1 \\ 2 & 1 & \end{array}$


electrophoresis using $5 \mu \mathrm{l}$ of DNA stained with 100x GelRed ${ }^{\mathrm{TM}}$ (Nucleic Acid Gel Stain, Biotium, Belgium). Samples were run at $100 \mathrm{~V}$ for $18 \mathrm{~min}$ in $0.5 \mathrm{x}$ TAE buffer and stored at $-20^{\circ} \mathrm{C}$ until further use.

\section{PCR, Cloning and Restriction Fragment Length Polymorphism (RFLP)}

For AMF species delimitation, an extended DNA barcode region which comprises a part of the SSU rRNA gene, the complete ITS region (including the 5.8S rRNA gene) and approx. $800 \mathrm{bp}$ of the LSU rRNA gene was amplified according to Krüger et al. (2009). The amplification requires a two-step PCR using AMF specific primers. For the first and nested PCR, the SSUmAf - LSUmAr and the SSUmCf - LSUmBr primer pairs were used, respectively. These primers have the widest taxon coverage when compared to other commonly used primers targeting a single nuclear rDNA marker (Kohout et al., 2014). Briefly, the reaction mix for both PCRs was done using the Phusion High Fidelity PCR Master Mix with HF Buffer (Thermo Fisher Scientific, Lithuania) with $0.5 \mu \mathrm{M}$ as a final primer concentration for each primer (Sigma, Germany) and $0.2 \mu \mathrm{g}$ $\mathrm{mL}^{-1}$ BSA (Albumin Bovine, AMRESCO, United States). Five $\mu \mathrm{L}$ of template DNA were used in $20 \mu \mathrm{L}$ of final reaction. Thermal cycling was done in an Eppendorf Master-cycler Gradient (Eppendorf Nexus X2, Germany) with the following conditions for the first PCR: Five min. initial denaturation at $99^{\circ} \mathrm{C} ; 40$ cycles of $10 \mathrm{~s}$. denaturation at $99^{\circ} \mathrm{C}, 30 \mathrm{~s}$. annealing at $60^{\circ} \mathrm{C}$ and 1 min elongation at $72^{\circ} \mathrm{C}$; and a $10 \mathrm{~min}$. final elongation. In the nested PCR, $1 \mu \mathrm{L}$ of the first PCR product was used as template in the same final reaction volume $(20 \mu \mathrm{L})$, the thermal cycling conditions were the same as for the first PCR, except that the annealing temperature was $63^{\circ} \mathrm{C}$ and only 30 cycles were done. The amplification results in a single $1.5 \mathrm{~kb}$ fragment with species resolution power (Stockinger et al., 2010).

Cloning as well as RFLPs were as described by Krüger et al. (2009). In brief, after a nested PCR amplification, PCR products were loaded on $1 \%$ agarose gel to determine positive amplification (see above). The $1.5 \mathrm{~kb}$ fragments were cloned with the Zero Blunt TOPO PCR Cloning Kit (Invitrogen, United States) following the manufacturer's protocol, with only one-third of the specified volume of all components used.

Forty eight clones from each cloning reaction were analyzed for correct length of plasmid inserts by colony-PCR using $1 \mathrm{x}$ GoTaq DNA Polymerase (Promega, United States) and M13FM13R primers.

To detect variable sequences between the clones, RFLPs with two different enzymes were performed in $10 \mu \mathrm{L}$ reaction volume, containing $5 \mu \mathrm{L}$ colony-PCR product, with one of the restriction enzymes Hinf I ( $1 \mathrm{U})$, or RsaI (1 U) and the specific buffer (Roche, Germany).

Selected clones (e.g., 12-29 per cloning reaction) were purified using the Invisorb Spin Plasmid Mini Two kit (STRACTEC, Germany) according to the manufacturer's protocol and sequenced using M13F-M13R primers at Macrogen Inc. (Korea).

\section{Sequence Assembly and Phylogenetic Analysis}

Sequences were assembled and edited with SeqMan (Lasergene, Madison, WI, United States). The search for homologous sequences was conducted by blastn at the National Center for Biotechnology information (NCBI) website and Blast2 $\mathrm{GO}^{2}$ (Conesa et al., 2005). Although a high-fidelity enzyme such as the Phusion DNA polymerase prevents chimera formation, sequences were checked manually to remove chimeric sequences. The AMF sequences were subsequently grouped into operational taxonomic units (OTUs) at a threshold of $\geq 97 \%$ sequence similarity, using the optimization of threshold-based linkage clustering runs from OPTSIL program (Goeker et al., 2009).

Nucleotide sequence alignments were performed with MAFFT version $7^{3}$ (Katoh and Standley, 2013), followed by manual adjustments using an AMF freely available reference alignment (Krüger et al., 2012) ${ }^{4}$ and environmental sequences from the NCBI platform at the Phylogenetic Data Editor $(\mathrm{PhyDE})^{5}$.

A maximum-likelihood phylogenetic tree was assembled with 256 reference and environmental sequences and 32 single representative sequences from each OTU using RAxML-HPC2 (Stamatakis et al., 2008) on XSEDE ver. 8.2.9 on the CIPRES Science Gateway ${ }^{6}$ with 1000 bootstrap and the GTRGAMMA model (Krüger et al., 2012). Taxonomic annotations follow the classification of Schüßler and Walker (2010). All variant sequences obtained from the clone library were deposited at NCBI with accession numbers MF589988-MF590019.

\section{Diversity Analysis}

Analysis of the community composition of AMF, in roots, was based on the number of clones (determined by analyzing the RFLP patterns) representing each AMF species (determined by phylogenetic analysis) present in the site and plant species. The Shannon diversity index $\left(\mathrm{H}^{\prime}\right)$, was calculated using the vegan package (Oksanen et al., 2017) in R Development Core Team (2016). The Shannon diversity index $\left(\mathrm{H}^{\prime}\right)$ was calculated using the diversity function by the formula $\mathrm{H}^{\prime}=-\Sigma$ pi $\log (\mathrm{b})$ pi, where pi is the proportional abundance of AMF species or genera $i$ and $b$ is the base of the logarithm ( Oksanen et al., 2017).

Principal component analysis (PCA) was used to analyze the similarity of the AMF community composition present in the plant species and the sites. Data were square root normalized and analyzed using the vegan package of $\mathrm{R}$ adjusting the total inertia to the number of variables.

\section{Statistical Analysis}

Statistical analyses were performed using the IBM SPSS statistic 22 software. Data for AMF root colonization percentage were analyzed by one way ANOVA. Normal distribution was checked and non-normal data were normalized by arcsine transformation

\footnotetext{
${ }^{2}$ https://www.blast2go.com/b2ghome

${ }^{3}$ http://mafft.cbrc.jp/alignment/software

${ }^{4} \mathrm{http}: / /$ www.amf-phylogeny.com

${ }^{5}$ http://www.phyde.de/

${ }^{6}$ http://www.phylo.org
} 


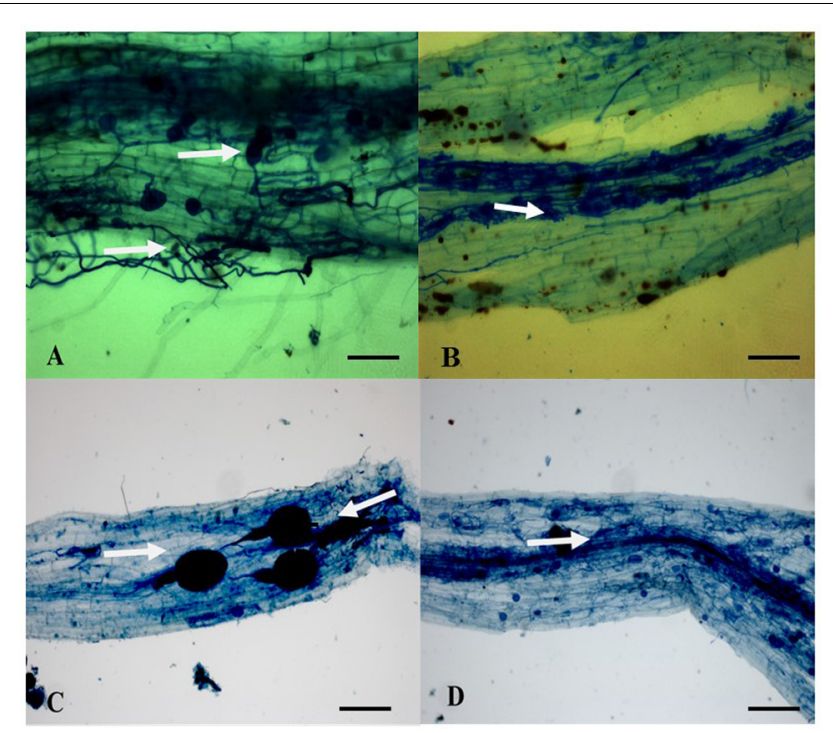

FIGURE 2 | Ink staining of AMF root colonization (Walker, 2005).

(A) Spores/vesicles (white arrow above), and hyphae (arrow below) in Carludovica palmata. (B) Arbuscules (white arrow) in Costus scaber. (C) Big spores/vesicles presenting a well -defined subtending hypha (white arrows) in Polybotrya sp. 2 (D) Hyphae (white arrow) in Euterpe precatoria. Scale bar (A,B) $300 \mu \mathrm{m}, \mathbf{( C , D )} 100 \mu \mathrm{m}$.

before analysis. One way ANOVA was used to determine significant difference between plant species and between sites AMF root colonization.

\section{RESULTS}

\section{AMF Root Colonization}

Regardless of the origin of the sample, root colonization was observed on all nine plant species (Pond 1 and 2 and surrounding soil) (Figure 2). All the plants surveyed had a total colonization percentage (\%TC) above $56 \% \pm 12.7$ and a total vesicle colonization percentage (\%VC) between $4 \% \pm 1.5$ and $20 \% \pm 18$ (Figure 3). Arbuscules were observed only in six plants out of the 48 observed [i.e., 1 (Costus pulverulentus), 2 (Costus scaber), 1 (Costus lima var. scabremarginatus), 1 (Carludovica palmata) and 1 (Monotagma sp. 1)]. The \%AC was between 1 and $12 \%$ (data not shown). Due to the presence of few representatives of some plant species and to preserve the plant diversity in the ponds, it was not always possible to sample the same plant species with the same number of replicate in the three sites (Table 1). However, no significant difference were observe in the \% $\mathrm{TC}$ or \%VC between plant species ( $P=0.216$ and $P=0.382$, respectively) (Figure 3 ) and between sites $(P=0.495$ and $P=0.284$, respectively - data not shown).

\section{AMF Root Diversity}

The nested PCR amplified the SSU-ITS-LSU (1.5 kb) rDNA region from all selected root samples. The number of sequences

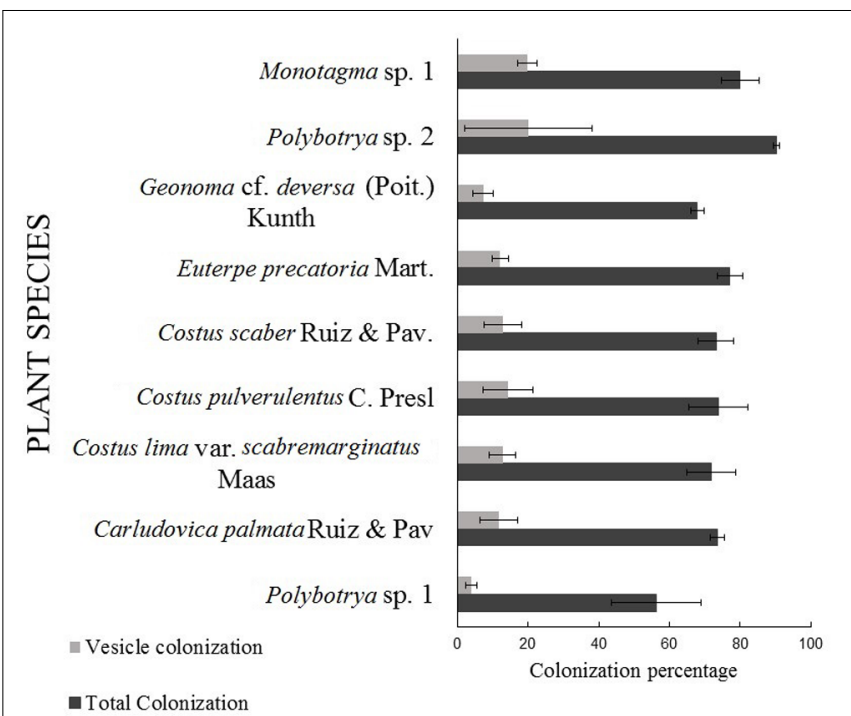

FIGURE 3 | Arbuscular mycorrhizal fungi total and intraradical spores/vesicles colonization (McGonigle et al., 1990) of plant species present in Ponds 1, 2 and surrounding soil. Data represent mean values and standard errors (SE) of 8 (Monotagma sp. 1), 2 (Polybotrya sp. 2), 3 (Geonoma cf. deversa), 13 (Euterpe precatoria.), 4 (Costus scaber), 3 (Costus pulverulentus), 6 (Costus lima), 6 (Carludovica palmata), 2 (Polybotrya sp. 1) replicates. No significant differences were observed on \%VC or \% TC between plant species $(P \leq 0.05$, Tukey HSD test).

amplified was 138. According to the clustering (threshold $\geq 97 \%$ ) by OPTSIL the sequences were grouped in 32 OTUs (Figure 4 and Table 2). Four AMF genera and seven species were detected in the roots of the three plant species examined by maximumlikelihood phylogeny. Based on homology in GenBank and the phylogenetic tree (Figure 4), the percentage of OTUs per AMF genus was 22\% (7 OTUs) of Rhizophagus, 31\% (10) of Glomus, 25\% (8) of Acaulospora and 22\% (7) of Archaeospora (Figure 5A). The genus Acaulospora was found in the three plant species in the two ponds but not in the surrounding soil. On the contrary, Rhizophagus was only observed in the surrounding soil specifically in E. precatoria. Glomus and Archaeospora were detected in all plant species in the three sites (Figures 6A-C and Table 2). According to AMF species, 5 OTUs (16\%) belonged to Rhizophagus proliferus and Acaulospora sp. (minutascrobiculata-like), 2 (6\%) belonged to Rhizophagus sp. and Acaulospora longula, 1 (3\%) to Acaulospora kentinensis, 10 (31\%) to Glomus sp., and 7 (22\%) to Archaeospora sp. (Figures 4, 5B). The distribution was similar at the genus-level.

Regardless of the site, the genera Rhizophagus sp. and $R$. proliferus were colonizing only E. precatoria. A. kentinensis was recorded only in C. palmata. Acaulospora sp. was shared between C. palmata and C. scaber. Finally Glomus sp., A. longula and Archaeospora sp. were revealed in the 3 plant species (Figures 7A-C and Table 2).

The PCA from the AMF community composition analyzed at the genus-level, demonstrated a similarity in the AMF community between C. palmata, C. scaber and Pond 2. Also similar are the communities present in E. precatoria and 


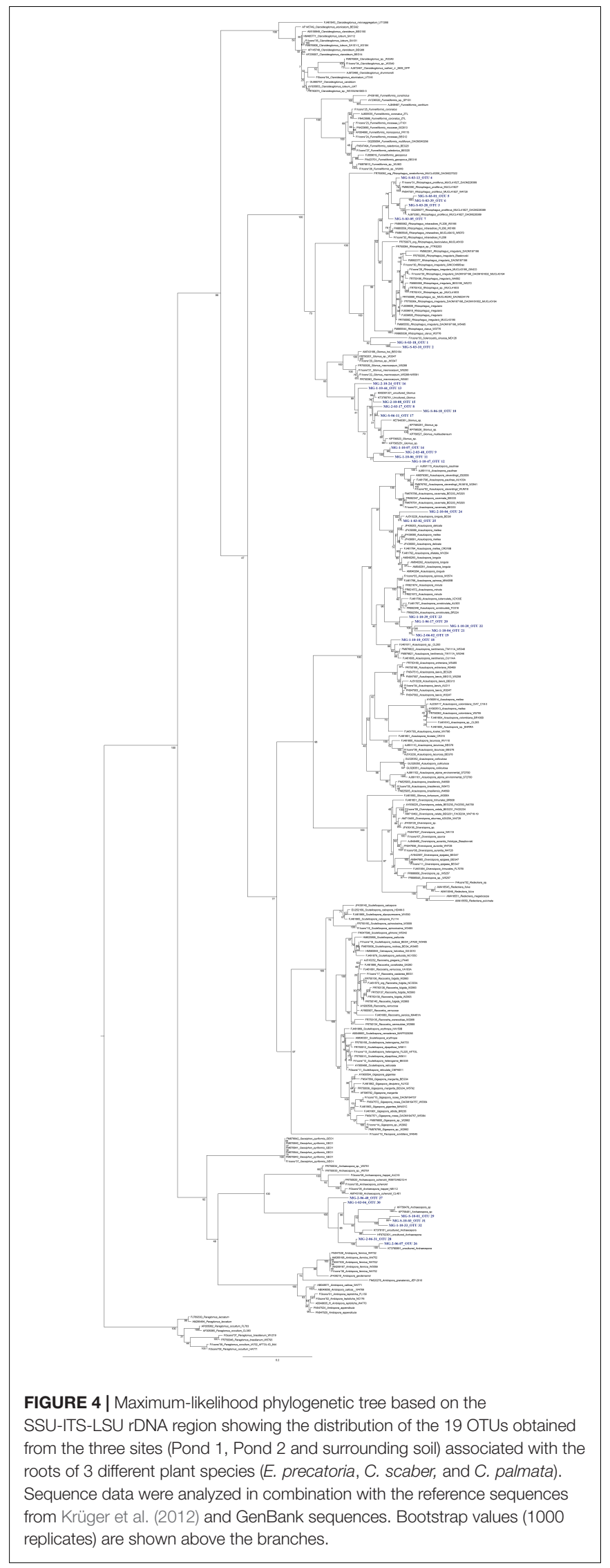

surrounding soil whereas Pond 1 was the most dissimilar (Figure 6D). A very similar pattern was observed when the AMF community composition was analyzed at the species-level (Figure 7D). Shannon diversity from AMF presented similar indices regardless of the site or plant species (Table 3).

\section{DISCUSSION}

Soils heavily contaminated by hydrocarbons are generally poor in plant and microbial diversity (Chibuike, 2013). Exploring AMF in hydrocarbon-polluted soils from natural environments (e.g., tropical rain forest) may provide unique information about the community composition and resilience of these root symbionts and their potentialities to protect plants from such stresses.

The presence of AMF in natural or polluted soils in the Amazonian basin of Ecuador has been poorly studied. The first report, to our knowledge, was made by Lunt and Hedger (1996) on the mycorrhizal colonization of trees in Terra Firme Cuyabeno, a wildlife reserve in the rainforest. They found that AMF colonization was the dominant mycorrhizal type but they did not study their diversity. Still today there are limited reports on AMF community composition in the Amazon region of Ecuador, contrary to the Amazon regions from Brazil, Colombia, Venezuela and Peru which have been much more explored (Janos and Sahley, 1995; Salamnaca and Silva, 1998; Peña-Venegas et al., 2006; Kalinhoff et al., 2009; Lopes Leal et al., 2009; Peña-Venegas, 2011; Stürmer and Siqueira, 2011).

Forty years ago, during the exploration of oil in the Charapa field, crude oil was spilled and accumulated in artificial ponds. Since then, a layer of organic matter consistently amassed allowing a variety of different trees and herbaceous plants to colonize and establish naturally. Total petroleum hydrocarbon (TPH) concentration inside the ponds and surrounding soil was high (i.e., above $5000 \mathrm{mg} \mathrm{Kg}^{-1}$ in Pond 1 and 2 and $\sim 1200 \mathrm{mg}$ $\mathrm{Kg}^{-1}$ in the surrounding soil) (Personal communication by Centro de Servicios Ambientales y Químicos - PUCE). The presence of TPH in the surrounding soil suggested lixiviation from the ponds. Pollution was thus observed in the three sites, although four times higher in the two ponds as compared to the surrounding soil.

The thorough analysis of plant species in the ponds as well in the surrounding soil, demonstrated the systematic presence of AMF in roots with levels of colonization above $50 \%$ in each species analyzed. Root colonization was observed for the first time in E. precatoria, C. scaber, C. palmata, Monotagma sp.1, Polybotrya sp.2, Geonoma cf. deversa, Costus pulverulentus, Costus lima, and Polybotrya sp.1 isolated from oil polluted soils. Nonetheless AMF association in some of these genera has been already revealed, due to its presence in the rhizosphere on natural, agriculture or greenhouse conditions (Trufem, 1990; Santos et al., 2000; Wang and Qiu, 2006; Reyes-Jaramillo et al., 2008).

Numerous hyphae and vesicles were observed but curiously few or no arbuscules in agreement with the findings of Iffis et al. (2016). These authors recorded the presence of vesicles and hyphae but no arbuscules in the roots of three plants species (i.e., Solidago canadensis, Populus balsamifera, and Lycopus europaeus) 
TABLE 2 | Operational taxonomic unit (OTUs) identification according to the site and plant species.

\begin{tabular}{|c|c|c|c|c|c|}
\hline Family & Genus & \# OTU & OTU species ID & Site & Plant species \\
\hline \multirow[t]{19}{*}{ Glomeraceae } & Rhizophagus & 1 & Rhizophagus sp. 1 & Surrounding soil & E. precatoria \\
\hline & & 2 & Rhizophagus sp. 1 & Surrounding soil & E. precatoria \\
\hline & & 3 & R. proliferus & Surrounding soil & E. precatoria \\
\hline & & 4 & R. proliferus & Surrounding soil & E. precatoria \\
\hline & & 5 & R. proliferus & Surrounding soil & E. precatoria \\
\hline & & 6 & R. proliferus & Surrounding soil & E. precatoria \\
\hline & & 7 & R. proliferus & Surrounding soil & E. precatoria \\
\hline & Glomus & 8 & Glomus sp. 1 & Pond 2 & E. precatoria \\
\hline & & 9 & Glomus sp. 1 & Pond 2 & E. precatoria \\
\hline & & 10 & Glomus sp. 1 & Surrounding soil & C. scaber \\
\hline & & 11 & Glomus sp. 1 & Pond 1 & C. palmata \\
\hline & & 12 & Glomus sp. 1 & Pond 1 & C. palmata \\
\hline & & 13 & Glomus sp. 1 & Pond 1 & C. palmata \\
\hline & & 14 & Glomus sp. 1 & Pond 1 & C. palmata \\
\hline & & & & Pond 2 & E. precatoria \\
\hline & & 15 & Glomus sp. 1 & Pond 2 & C. palmata \\
\hline & & 16 & Glomus sp. 1 & Pond 2 & C. palmata \\
\hline & & 17 & Glomus sp. 1 & Pond 2 & E. precatoria C. palmata \\
\hline & & & & Surrounding soil & C. scaber \\
\hline \multirow[t]{9}{*}{ Acaulosporaceae } & Acaulospora & 18 & A. kentinensis & Pond 1 & C. palmata \\
\hline & & 19 & Acaulospora sp. 1 & Pond 2 & C. scaber \\
\hline & & 20 & Acaulospora sp. 1 & Pon1, Pond 2 & C. scaber \\
\hline & & 21 & Acaulospora sp. 1 & Pond 1 & C. palmata \\
\hline & & 22 & Acaulospora sp. 1 & Pond 1 & C. palmata \\
\hline & & 23 & Acaulospora sp. 1 & Pond 1 & C. palmata \\
\hline & & 24 & A. longula & Pond 2 & C. palmata \\
\hline & & 25 & A. longula & Pond 1 & E. precaria, C. scaber \\
\hline & & & & Pond 2 & C. palmata \\
\hline \multirow[t]{8}{*}{ Archaeosporacea } & Archaeospora & 26 & Archaeospora sp. 1 & Pond 2 & C. scaber \\
\hline & & 27 & Archaeospora sp. 1 & Pond 2 & C. scaber \\
\hline & & 28 & Archaeospora sp. 1 & Pond 2 & C. scaber \\
\hline & & 29 & Archaeospora sp. 1 & Surrounding soil & C. palmata \\
\hline & & 30 & Archaeospora sp. 1 & Pond 1 and 2 & E. precaria, C. scaber \\
\hline & & & & Pond 1 & C. palmata \\
\hline & & 31 & Archaeospora sp. 1 & Surrounding soil, Pond 1 & C. palmata \\
\hline & & 32 & Archaeospora sp. 1 & Pond 1 & C. palmata \\
\hline
\end{tabular}
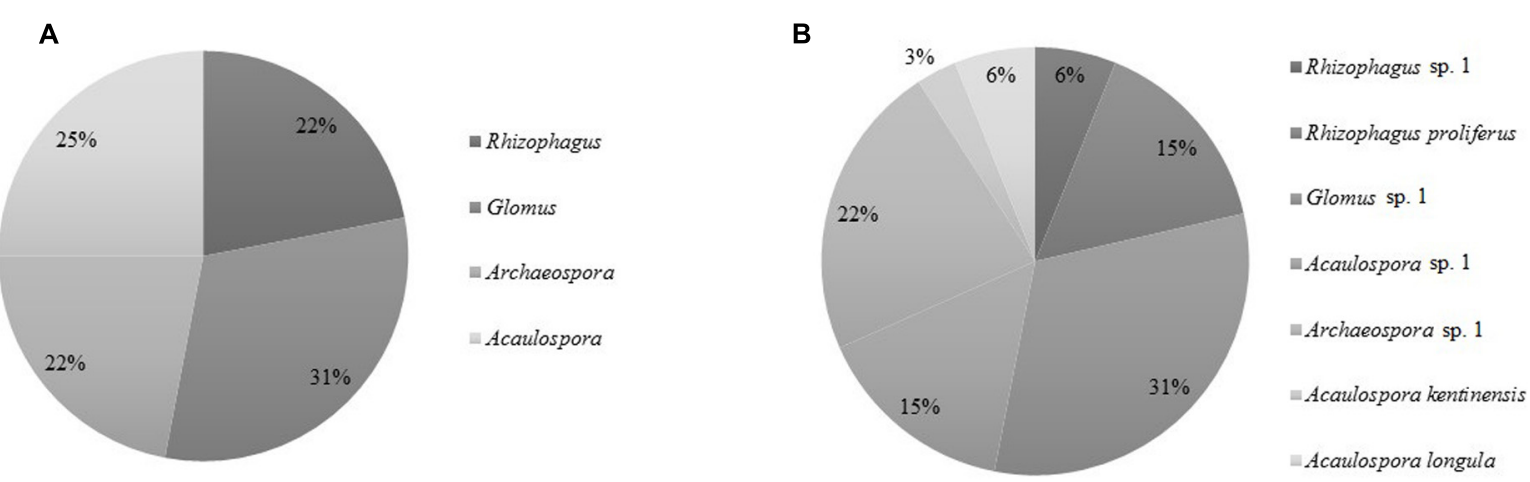

FIGURE 5 | Occurrence of AMF Operational Taxonomic Units (OTUs) according to the (A) percentage of OTUs representing Glomeromycota genera, (B) percentage of OTUs representing Glomeromycota species independently of the site or plant species. 


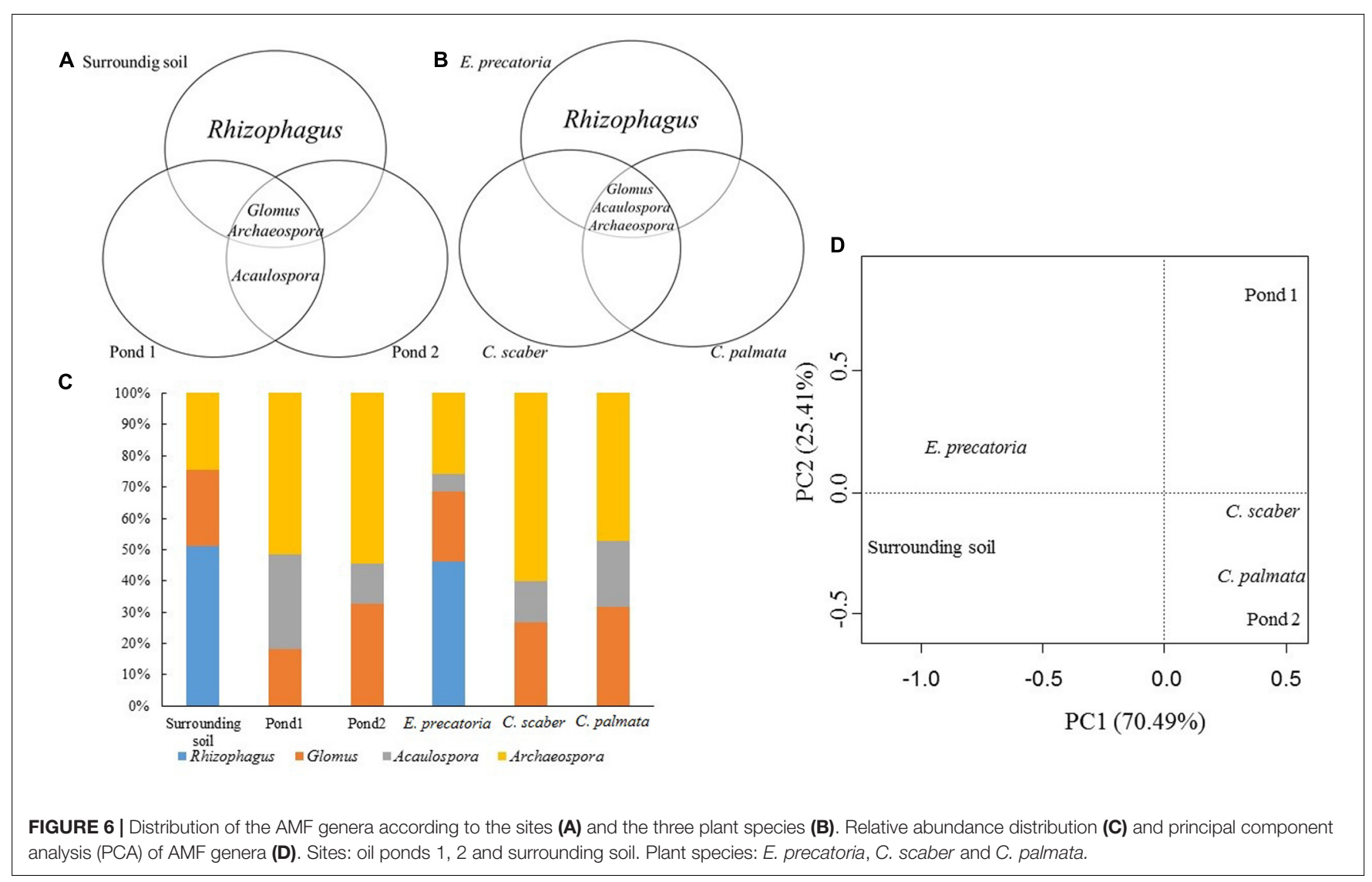

growing in petroleum hydrocarbon wastes of three decantation basins from a former petrochemical plant, located on the south shore of the St-Lawrence River near Montreal (Canada). This very low or erratic occurrence of arbuscules could be attributed to several factors among which is the presence of pollutants as suggested by Cabello (1997). Interestingly, in soils contaminated by heavy metals, both Sonjak et al. (2009) and Maček et al. (2016) reported a low frequency or absence of arbuscules in the roots of plants naturally colonizing these soils.

An in-deep community analysis was conducted on C. scaber, E. precatoria and C. palmata because these plants are known to form associations with AMF (Janos, 1980; Santos et al., 2000; Wang and Qiu, 2006; Janos, 2007; Lopes Leal et al., 2009; Stürmer and Siqueira, 2011) and they were present in the two contiguous oil ponds and surrounding soil of the Charapa field study. To our knowledge, no information on AMF communities associated with these species exist. A number of AMF species belonging to Acaulospora, Entrophospora and Glomus were detected in an agroforestry system at the Upper Solimões River, at the heart of the Amazon region in Brazil, in which E. precatoria was present along with other plants known as regenerating species from secondary forest. Though no root colonization or AMF species diversity within roots was evaluated (Lopes Leal et al., 2009; Stürmer and Siqueira, 2011). Similarly, C. palmata (Janos, 1980, 2007) and C. scaber (Santos et al., 2000) are highly mycotrophic plants but the AMF communities in their roots remain undescribed.
Interestingly, from the DNA extraction of roots of the three plant species, four AMF genera (Rhizophagus, Glomus, Acaulospora, and Archaeospora) were detected. The taxonomic diversity at the genera level was low, although seven species within 138 AMF sequences were obtained for a total of 10, 8, 7 and 7 different OTUs within Glomus, Acaulospora, Rhizophagus and Archaeospora, respectively. Hassan et al. (2014) and de la Providencia et al. (2015) revealed a higher number of OTUs (27 and 21, respectively) in different hydrocarbon-polluted soils, although they analyzed a much larger number of sequences with a different molecular marker (69282 AMF 18S rDNA sequences from 454-pyrosequencing and 824 AMF 18S rDNA Sanger sequences).

The presence of Archaeospora was detected in $22 \%$ of the total number of OTUs. This family was present in the three sites and associated with all plant species analyzed. However, all the sequences were represented by unknown Archaeospora spp. (OTUs 24-32) in several well-resolved phylogenetic clades (Figure 4), suggesting the presence of new species. This genus was not reported when the $18 \mathrm{~S}$ rDNA was sequenced in the studies of de la Providencia et al. (2015) and Iffis et al. (2016) on hydrocarbon-polluted soils. However Iffis et al. (2016) reported, in the same study, low abundance of unclassified Archaeosporaceae using the AMF ITS dataset. Similarly, Cabello (1997) and Villacrés et al. (2014) using classical spores taxonomy never described this genus in hydrocarbon-polluted soils. Hassan et al. (2014) and Iffis et al. (2014, 2016) recorded virtual 


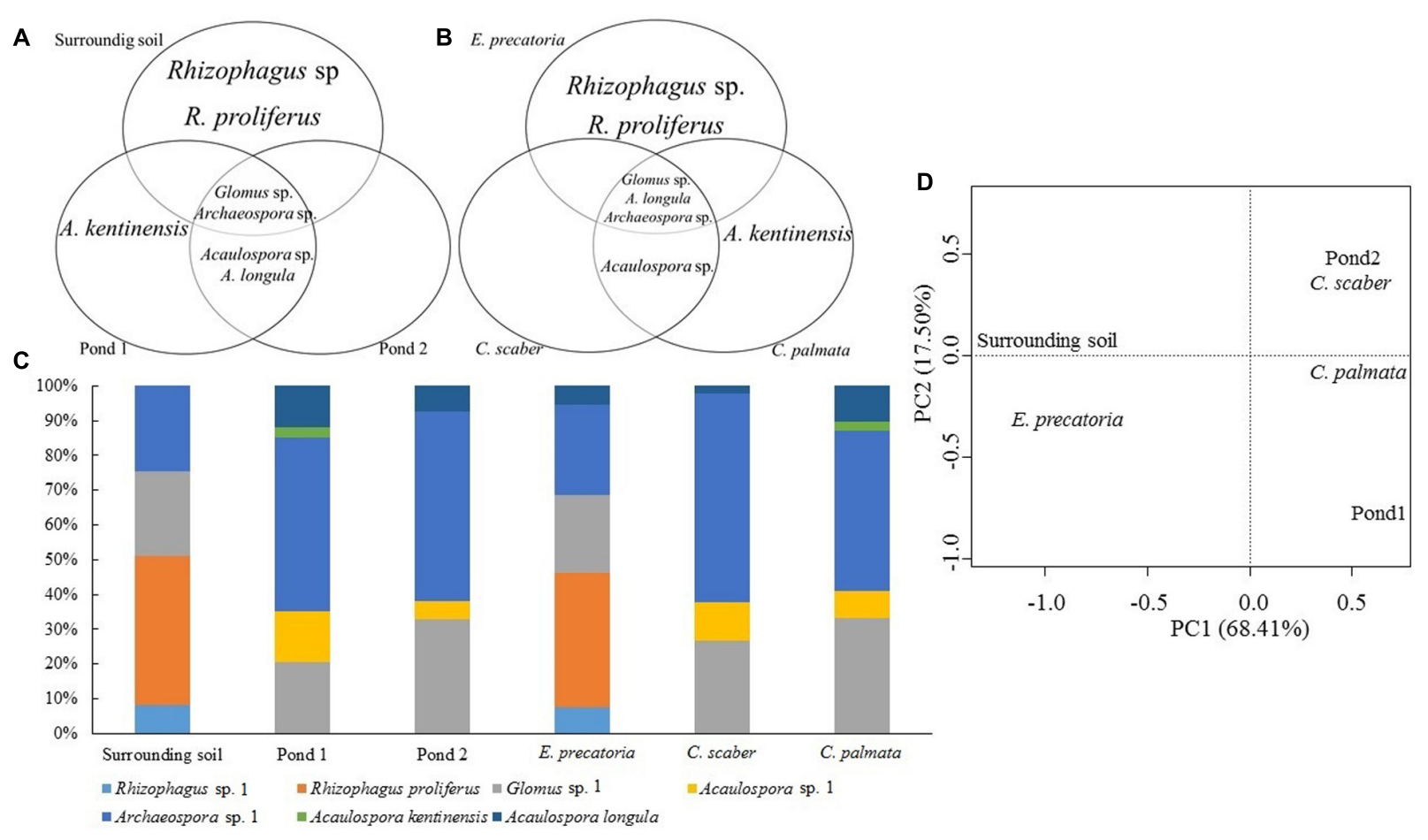

FIGURE 7 | Distribution of the AMF species according to the sites (A) and the three plant species (B). Relative abundance distribution (C) and principal component analysis (PCA) of AMF species (D). Sites: oil ponds 1, 2 and surrounding soil. Plant species: E. precatoria, C. scaber and C. palmata.

taxa belonging to Archaeosporacea with a molecular approach in soils from a phytoremediation field trial at the site of a former petrochemical plant in Varennes and St-Lawrence River, Canada, respectively. Interestingly, Peña-Venegas (2011) have documented two species of Archaeospora (Archaeospora leptoticha and Archaeospora trappei) in the Amazonian region of Brazil and one in Colombia (A. leptoticha) demonstrating the presence of these genera in the Amazonian region. Further one phylotype belonged to this genus was recorded in roots of Prunus persica under two types of fertilization (inorganic, with or without manure) in a tropical agro-ecosystem of Venezuela (Alguacil Mdel et al., 2014).

The genus Acaulospora was found in $25 \%$ of the total number of OTUs. This genus was present in both ponds but not in the surrounding soil. Two OTUs belonged to A. longula (OTU 24 and 25) and 1 was related to Acaulospora kentinensis (OTU 18) and putatively unknown Acaulospora spp. (OTU 19-23), suggesting undescribed new species. The Acaulosporacea family has been defined as a stress-tolerant AMF due to its capacity to complete its life cycle with low biomass production that would thus reduce exposure to abiotic stress agents (Chagnon et al., 2013). This family was recorded in hydrocarbon-polluted soils with a predominance of $16 \%$ of the total number of species detected (Iffis et al., 2016). Villacrés et al. (2014) also noticed, by spores morpho-analysis, a predominance of Acaulospora as well as Glomus in hydrocarbon-polluted soils from the Orellana province in the Amazon region of Ecuador. Conversely, de la Providencia et al. (2015) obtained only a single OTU belonging to Acaulospora, associated with Eleocharis obtusa and Panicum capillare. Hassan et al. (2014) did not detect any Acaulospora spp. in Willow (Salix spp. L.) under hydrocarbon-polluted conditions. These suggest that the presence of Acaulospora spp. is not related to hydrocarbon contamination, but can be associated with the Ecuadorian Amazon region.

Finally, the predominance of Glomus (31\%) with 10 different OTUs detected in the roots of the three plants species from the ponds and surrounding soil was in agreement with several studies that revealed the predominance of Glomeraceae in hydrocarbon-polluted soils (Cabello, 1997; Hassan et al., 2014; Villacrés et al., 2014; de la Providencia et al., 2015). The Rhizophagus genus was represented by 5 OTUs of $R$. proliferus (OTUs 3 to 7; synonymous of Glomus proliferum), 2 OTUs of Rhizophagus sp. closely related to Sclerocystis sinuosa (OTUs 1 and 2), revealing again the possibility of undescribed new species. Chagnon et al. (2013) determined that the Glomeraceae family has the capacity to colonize roots faster and that their extraradical hyphae abundance is higher than other AMF families (i.e., Acaulosporaceae, Gigasporaceae). This family is considered to have a ruderal life history, in agreement with its dominance in polluted environments. However, the OTUs belonging to the genus Rhizophagus were observed only in the surrounding soil in one plant species (E. precatoria). Conversely Glomus spp. were observed in all sites in all plant roots. Thus E. precatoria presented the most elevated percentage $(58 \%)$ of OTUs compared to C. scaber $(47 \%)$ and C. palmata (37\%). Rhizophagus was dominant with 5 


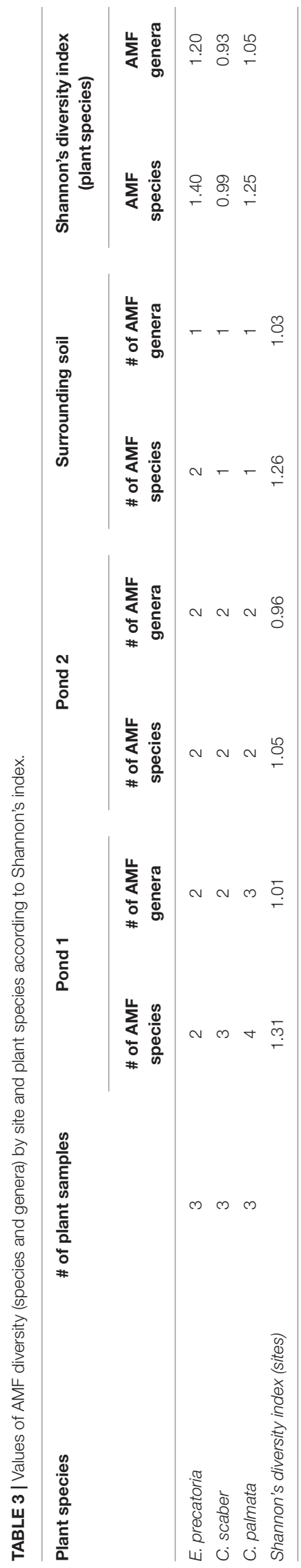

different OTUs according to the clustering (threshold $\geq 97 \%$ ) by OPTSIL. Hassan et al. (2014) and de la Providencia et al. (2015) showed an elevated occurrence of Rhizophagus in hydrocarbon-polluted rhizosphere. Conversely de la Providencia et al. (2015) demonstrated that the AMF community structure in roots was totally different compared to the rhizosphere in the sediments associated with E. obtusa and P. capillare, where just one OTU belonging to the Rhizophagus genus was recorded.

These three AMF families (i.e., Glomeraceae, Acaulosporaceae, and Archaeosporaceae) have also been recorded associated with plants in the tropical mountain rain forest in the San Francisco River, Cordillera Real, in the south of Ecuador after reforestation experiments with local trees species (Cedrela montana Moritz ex Turcz., Heliocarpus americanus L., Juglans neotropica Diels and Tabebuia chrysantha (Jacq.) G. Nicholson) where 40 year old abandoned pastures were compared with old trees from the nearest pristine forest (Haug et al., 2010). Moreover, in potato crops in the Andean region of Ecuador, the same genera as the ones found in our study were detected and several Acaulospora spp. were recorded as the main root colonizers (Senés-Guerrero and Schüßler, 2016a). These results suggest a prevalence of these families in different environmental conditions in Ecuador. Thus, these AMF families could be considered as widely distributed and adapted to an extensive range of host plants and soil conditions in Ecuador. Indeed, a global assessment of AMF diversity revealed a high number of AMF taxa shared between continents (Davison et al., 2015), suggesting that dispersal mechanism such as wind, animals and human activities are responsible of their distribution in all kind of vegetative communities.

Additionally, results from de la Providencia et al. (2015) and our results showed the presence of almost all families of Glomeromycota with exception of Ambisporaceae, Geosiphonaceae, and Pacisporaceae in oil-polluted soils with abundance varying depending on environmental conditions (rainforest) as well as on the levels of pollution and native flora. Suggesting, one again, the world-wide distribution of these three families.

For the first time, AMF community composition was studied in crude oil ponds in a natural environment from the Amazon basin of Ecuador via molecular tools. Roots from several native plants species were highly colonized and diverse communities of AMF belonging to Glomus, Rhizophagus, Archaeospora and Acaulospora were associated with C. scaber, E. precaria and C. palmata. Seventy four percent of OTUs could not be ascribed to an existing AMF species suggesting the presence of a high number of potential new species. This is in agreement with global AMF molecular surveys where many unknown species are living in unstudied areas (Kivlin et al., 2011; Öpik et al., 2013) such as the Tibetan Plateau (Li et al., 2015) and the Andean region (Senés-Guerrero et al., 2014), suggesting that the diversity within this group of fungi is still underestimated. The unexpectedly high percentage of AMF colonization of the roots from plants growing in the hydrocarbon-polluted ponds of the Charapa field, further 
suggested that the AMF taxa found were able to adapt to these harsh conditions, representing potentially interesting strains for plant establishment and remediation of polluted soils.

\section{ETHICS STATEMENT}

Permits were given by the public enterprise PetroAmazonas EP for sampling and field study. The field study did not involve endangered or protected species.

\section{AUTHOR CONTRIBUTIONS}

MG-R: sampling, development of samples analysis, data collection, data analysis, interpretation of data. Drafting the work, commentaries corrections, final approval and agreement with all aspects of the work. CS-G: contribution to the analysis and interpretation of the data, draft correction and final approval and agreement with all aspects of the work. SD: contributions to analysis of the results, draft corrections final approval and agreement with all aspects of the work. SC: substantial

\section{REFERENCES}

Abbott, L. K., and Lumley, S. (2014). Mycorrhizal Fungi: Use in Sustainable Agriculture and Land Restoration. Berlin: Springer.

Alguacil, M. d. M., Torrecillas, E., Lozano, Z., Torres, M. P., and Roldán, A. (2014). Prunus persica crop management differentially promotes arbuscular mycorrhizal fungi diversity in a tropical agro-ecosystem. PLOS ONE 9:e88454. doi: 10.1371/journal.pone.0088454

Armstrong, A. G., and Vallejo, M. (1997). TED Case Studies, Ecuador Oil Exports. Database Trade and Environment TED. Available at: https://web.archive.org/ web/20120215032700/http://www1.american.edu/ted/ecuador.htm [accessed 26 October, 2017].

Bever, J. D., Morton, J. B., Antonovics, J., and Schultz, P. A. (1996). Host-dependent sporulation and species diversity of arbuscular mycorrhizal fungi in a mown grassland. J. Ecol. 84, 71-82. doi: 10.2307/2261701

Buysens, C., César, V., Ferrais, F., de Boulois, H. D., and Declerck, S. (2016). Inoculation of Medicago sativa cover crop with Rhizophagus irregularis and Trichoderma harzianum increases the yield of subsequently-grown potato under low nutrient conditions. Appl. Soil Ecol. 105, 137-143. doi: 10.1016/j. apsoil.2016.04.011

Cabello, M. (1997). Hydrocarbon pollution: its effect on native arbuscular mycorrhizal fungi (AMF). FEMS Microbiol. Ecol. 22, 233-236. doi: 10.1016/ S0168-6496(96)00094-3

Cabello, M. N. (1999). Effectiveness of indigenous arbuscular mycorrhizal fungi (AMF) isolated from hydrocarbon polluted soils. Basic Microbiol. 39, 89-95. doi: 10.1002/(SICI)1521-4028(199905)39:2<89::AID-JOBM89>3.0. $\mathrm{CO} ; 2-\mathrm{D}$

Chagnon, P. L., Bradley, R. L., Maherali, H., and Klironomos, J. N. (2013). A traitbased framework to understand life history of mycorrhizal fungi. Trends Plant Sci. 18, 484-491. doi: 10.1016/j.tplants.2013.05.001

Chibuike, G. U. (2013). Use of mycorrhiza in soil remediation: a review. Sci. Res. Essays 8, 1679-1687. doi: 10.5897/SRE2013.5605

Clapp, J. P., Young, J. P. W., Merryweather, J. W., and Fitter, A. H. (1995). Diversity of fungal symbionts in arbuscular mycorrhizas from a natural community. New Phytol. 130, 259-265. doi: 10.1111/j.1469-8137.1995.tb03047.x

Conesa, A., Götz, S., García-Gómez, J. M., Terol, J., Talón, M., and Robles, M. (2005). Blast2GO: a universal tool for annotation, visualization and analysis in functional genomics research. Bioinformatics 21, 3674-3676. doi: 10.1093/ bioinformatics/bti610 contributions from conception to data analysis, draft correction and final approval and agreement with all aspects of the work.

\section{ACKNOWLEDGMENTS}

This research was supported by the CIUF-CUD (currently ARES, Académie de Recherche et d'enseignement Supérieur WallonieBruxelles, Commission de la Coopération pour le Dévelopment CIUF) through the PIC Project entitled 'Reinforcement of the fungal expertise in Ecuador via case studies of fungal plants interactions in selected ecosystems and the development of biotechnology-oriented fungal resource'. MG-R was also supported by the Pontificia Universidad Católica del Ecuador (PUCE). We thank PetroAmazonas EP (public enterprise of Ecuador) for granting us access to the Charapa field and providing their infrastructure. We are also grateful to Mrs. Céline Bivort (UCL) for the molecular work, to Dr. Juan Pablo Suarez and his team (Departamento de Ciencias Naturales Universidad Técnica Particular de Loja) for the help in the Operational Taxonomic Units (OTU) analysis and to Alvaro Pérez, botanist of PUCE, Facultad de Ciencia Exactas y Naturales to characterize the flora ecosystem of the Charapa field.

Davison, J., Moora, M., Öpik, M., Adholeya, A., Ainsaar, L., Bâ, A., et al. (2015). Global assessment of arbuscular mycorrhizal fungus diversity reveals very low endemism. Science 127, 970-973. doi: 10.5061/dryad.2m15n

de la Providencia, I. E., Stefani, F. O. P., Labridy, M., St-Arnaud, M., and Hijri, M. (2015). Arbuscular mycorrhizal fungal diversity associated with Eleocharis obtusa and Panicum capillare growing in an extreme petroleum hydrocarbonpolluted sedimentation basin. FEMS Microbiol. Lett. 362:fnv081. doi: 10.1093/ femsle/fnv081

Declerck, S., Cranenbrouck, S., Dalpe, Y., Seguin, S., Grandmougin-Ferjani, A., Fontaine, J., et al. (2000). Glomus proliferum sp. nov.: a description based on morphological, biochemical, molecular and monoxenic cultivation data. Mycologia 92, 1178-1187. doi: 10.2307/3761485

Declerck, S., Strullu, D. G., and Plenchette, C. (1998). Monoxenic culture of the intraradical forms of Glomus sp. isolated from a tropical ecosystem: a proposed methodology for germplasm collection. Mycologia 90, 579-585. doi: 10.2307/ 3761216

Dodd, J. C. (2000). The role of arbuscular mycorrhizal fungi in agro-and natural ecosystems. Outlook Agric. 29, 55-62. doi: 10.5367/0000000001012 93059

Ferrol, N., Tamayo, E., and Vargas, P. (2016). The heavy metal paradox in arbuscular mycorrhizas: from mechanisms to biotechnological applications. J. Exp. Bot. 67, 6253-6265. doi: 10.1093/jxb/erw403

Gil-Cardeza, M. L., Ferri, A., Cornejo, P., and Gomez, E. (2014). Distribution of chromium species in a Cr-polluted soil: presence of $\mathrm{Cr}(\mathrm{III})$ in glomalin related protein fraction. Sci. Total Environ. 493, 828-833. doi: 10.1016/j.scitotenv.2014. 06.080

Goeker, M., García-Blázquez, G., Voglmayr, H., Tellería, M. T., and Martín, M. P. (2009). Molecular taxonomy of phytopathogenic fungi: a case study in Peronospora. PLOS ONE 4:e6319. doi: 10.1371/journal.pone. 0006319

Hassan, S. E.-D., Bell, T. H., Stefani, F. O. P., Denis, D., Hijri, M., and St-Arnaud, M. (2014). Contrasting the community structure of arbuscular mycorrhizal fungi from hydrocarbon-contaminated and uncontaminated soils following willow (Salix spp. L.) planting. PLOS ONE 9:e102838. doi: 10.1371/journal.pone. 0102838

Haug, I., Wubet, T., Weiß, M., Aguirre, N., Weber, M., Günter, S., et al. (2010). Species-rich but distinct arbuscular mycorrhizal communities in reforestation plots on degraded pastures and in neighboring pristine tropical mountain rain forest. Trop. Ecol. 51, 125-148. 
Homeier, J., Leuschner, C., Bräuning, A., Cumbicus, N. L., Hertel, D., Martinson, G. O., et al. (2013). Ecosystem Services, Biodiversity and Environmental Change in a Tropical Mountain Ecosystem of South Ecuador, Vol. 221, eds J. Bendix, E. Beck, A. Bräuning, F. Makeschin, R. Mosandl, S. Scheu, et al. Berlin: Springer-Verlag.

Iffis, B., St-Arnaud, M., and Hijri, M. (2014). Bacteria associated with arbuscular mycorrhizal fungi within roots of plants growing in a soil highly contaminated with aliphatic and aromatic petroleum hydrocarbons. FEMS Microbiol. Lett. 358, 44-54. doi: 10.1111/1574-6968.12533

Iffis, B., St-Arnaud, M., and Hijri, M. (2016). Petroleum hydrocarbon contamination, plant identity and arbuscular mycorrhizal fungal (AMF) community determine assemblages of the AMF spore-associated microbes. Environ. Microbiol. 18, 2689-2704. doi: 10.1111/1462-2920.13438

Janos, D. P. (1980). Vesicular-arbuscular mycorrhizae affect lowland tropical rain forest plant growth. Ecol. Soc. Am. 61, 151-162. doi: 10.2307/1937165

Janos, D. P. (2007). Plant responsiveness to mycorrhizas differs from dependence upon mycorrhizas. Mycorrhiza 17, 75-91. doi: 10.1007/s00572-006-0094-1

Janos, D. P., and Sahley, C. T. (1995). Rodent dispersal of vesicular-arbuscular mycorrhizal fungi in Amazonian Peru. Ecol. Stud. 76, 1852-1858. doi: 10.2307/ 1940717

Kalinhoff, C., Cáceres, A., and Lugo, L. (2009). Cambios en la biomasa de raíces y micorrizas arbusculares en cultivos itinerantes del Amazonas venezolano. Interciencia 34, 571-576.

Katoh, K., and Standley, D. M. (2013). MAFFT multiple sequence alignment software version 7: improvements in performance and usability. Mol. Biol. Evol. 30, 772-780. doi: 10.1093/molbev/mst010

Kivlin, S. N., Hawkes, C. V., and Treseder, K. K. (2011). Global diversity and distribution of arbuscular mycorrhizal fungi. Soil Biol. Biochem. 43, 2294-2303. doi: 10.1016/j.soilbio.2011.07.012

Kohout, P., Sudová, R., Janoušková, M., Čtvrtlíková, M., Hejda, M., Pánková, H., et al. (2014). Comparison of commonly used primer sets for evaluating arbuscular mycorrhizal fungal communities: Is there a universal solution? Soil Biol. Biochem. 68, 482-493. doi: 10.1016/j.soilbio.2013.08.027

Krüger, M., Krüger, C., Walker, C., Stockinger, H., and Schüßler, A. (2012). Phylogenetic reference data for systematics and phylotaxonomy of arbuscular mycorrhizal fungi from phylum to species level. New Phytol. 193, 970-984. doi: 10.1111/j.1469-8137.2011.03962.x

Krüger, M., Stockinger, H., Krüger, C., and Schüßler, A. (2009). DNA-based species level detection of Glomeromycota: one PCR primer set for all arbuscular mycorrhizal fungi. New Phytol. 183, 212-223. doi: 10.1111/j.1469-8137.2009. 02835.x

Li, X., Zhang, J., Gai, J., Cai, X., Christie, P., and Li, X. (2015). Contribution of arbuscular mycorrhizal fungi of sedges to soil aggregation along an altitudinal alpine grassland gradient on the Tibetan Plateau. Environ. Microbiol. 17, 2841-2857. doi: 10.1111/1462-2920.12792

Liang,grown in multi-metal contaminated soils. Int. J. Phytoremediation C.-C., Tao, L., Yan-Ping, X., Mao-Jun, L., Han-Bo, Z., and Zhao, Z.-W. (2009). Effects of inoculation with arbuscular mycorrhizal fungi on maize 11, 692-703. doi: 10.1080/15226510902787310

Lopes Leal, P., Stürmer, S. L., and Siqueira, J. O. (2009). Occurrence and diversity of arbuscular mycorrhizal fungi in trap cultures from soils under different land use systems in the Amazon, Brazil. Braz. J. Microbiol. 40, 111-121. doi: 10.1590/S1517-83822009000100019

Lunt, P. H., and Hedger, J. N. (1996). A survey of mycorrhizal infection of trees in the terra firme rainforest, Cuyabeno, Ecuador. Mycologist 10, 161-165. doi: 10.1016/S0269-915X(96)80010-3

Maček, I., Šibanc, N., Kavšček, M., and Lestan, D. (2016). Diversity of arbuscular mycorrhizal fungi in metal polluted and EDTA washed garden soils before and after soil revitalization with commercial and indigenous fungal inoculum. Ecol. Eng. 95, 330-339. doi: 10.1016/j.ecoleng.2016.06.026

Ministerio del Ambiente de Ecuador [MAE] (2015). Percentage of Pollution Sources of Hydrocarbon Industry Eliminated, Remedied and Endorsed by the Environmental National Authority. Ministerio Del Ambiente Ecuador. Available at: http://snia.ambiente.gob.ec:8090/indicadoresambientales/pages/ indicators.jsf

McGonigle, T. P., Miller, M. H., Evans, D. G., Fairchild, G. L., and Swan, J. A. (1990). A new method which gives an objective measure of colonization of roots by vesicular-arbuscular mycorrhizal fungi. New Phytol. 115, 495-501. doi: 10.1111/j.1469-8137.1990.tb00476.x

Oksanen, J., Blanchet, F. G., Friendly, M., Kindt, R., Legendre, P., McGlinn, D., et al. (2017). Vegan: Community Ecology Package. R Package Version 2.4-3. Available at: http://cran.r-project.org/package=vegan

Öpik, M., Zobel, M., Cantero, J. J., Davison, J., Facelli, J. M., Hiiesalu, I., et al. (2013). Global sampling of plant roots expands the described molecular diversity of arbuscular mycorrhizal fungi. Mycorrhiza 23, 411-430. doi: 10.1007/s00572-013-0482-2

Palacios, W., Cerón, C., Valencia, R., Sierra, R. (1999). "Las formaciones naturales de la amazonía del ecuador," in Propuesta Preliminar de un Sistema de Clasificación de Vegetación para el Ecuador Continental, ed. R. Sierra (Proyecto INEFAN/GEF-BIRF y EcoCiencia: Quito), 109-119.

Peña-Venegas, C. P. (2011). “Arbuscular mycorrhizal fungi in the Amazon region," in Mycorrhiza: Occurrence in Natural and Restored Environments, ed. M. Pagano (Paris: Nova Press), 75-86.

Peña-Venegas, C. P., Cardona, G. I., Mazorra, A., Arguellez, J. H., and Arcos, A. L. (2006). Micorrizas Arbusculares de La Amazonia Colombiana. Bogotá: Instituto Amazónico de Investigaciones Científicas SINCHI.

Plouznikoff, K., Declerck, S., and Calonne-Salmon, M. (2016). "Mitigating abiotic stresses in crop plants by arbuscular mycorrhizal fungi," in Belowground Defence Strategies in Plants, Signaling and Communication in Plants, eds C. M. F. Vos and K. Kazan (Switzerland: Springer International Publishing), 341-400. doi: 10.1007/978-3-319-42319-7

R Development Core Team (2016). R: A Language and Environment for Statistical Computing. Vienna: R Foundation for Statistical Computing.

Rajtor, M., and Piotrowska-Seget, Z. (2016). Prospects for arbuscular mycorrhizal fungi (AMF) to assist in phytoremediation of soil hydrocarbon contaminants. Chemosphere 162, 105-116. doi: 10.1016/j.chemosphere.2016.07.071

Reyes-Jaramillo, I., Camargo-Ricalde, S. L., and Aquiahuatl-Ramos, M. L. (2008). Mycorrhizal-like interaction between gametophytes and young sporophytes of the fern Dryopteris muenchii (Filicales) and its fungal endophyte. Rev. Biol. Trop. 56, 1101-1107.

Rillig, M. C. (2004). Arbuscular mycorrhizae, glomalin, and soil aggregation. Can. J. Soil Sci. 84, 355-363. doi: 10.4141/S04-003

Rillig, M. C., Camenzind, T., Gawlik, J., Haug, I., Maraun, V. K. M., and Scheu, D. S. S. (2013). "Diversity in soil fungi, protists, and microarthropods," in Ecosystem Services, Biodiversity and Environmental Change in a Tropical Mountain Ecosystem of South Ecuador, eds J. Bendix, E. Beck, A. Bräuning, F. Makeschin, R. Mosandl, S. Scheu, et al. (Berlin: Springer-Verlag), 80-92. doi: 10.1007/978-3-642-38137-9

Robertson, S. J., McGill, W. B., Massicotte, H. B., and Rutherford, P. M. (2007). Petroleum hydrocarbon contamination in boreal forest soils: a mycorrhizal ecosystems perspective. Biol. Rev. 82, 213-240. doi: 10.1111/j.1469-185X.2007. 00012.x

Salamnaca, C. R., and Silva, M. D. R. (1998). Las micorrizas como alternativa para el manejo sostenible de los agroecosistemas tropicales. Boletin Tecnico Corpoica $12,26$.

Santos, B. A., Silva, G. A., Maia, L. C., and Alves, M. V. (2000). Mycorrhizae in monocotyledonae of Northeast Brazil: subclasses Alismatidae, Arecidae and Zingiberidae. Mycorrhiza 10, 151-153. doi: 10.1007/s005720000068

Schüßler, A., Krüger, C., and Urgiles, N. (2015). Phylogenetically diverse AM fungi from Ecuador strongly improve seedling growth of native potential crop trees. Mycorrhiza 26, 199-207. doi: 10.1007/s00572-015-0659-y

Schüßler, A., and Walker, C. (2010). The Glomeromycota: A Species List with New Families and New Genera. Available at: www.amf-phylogeny.com

Senés-Guerrero, C., and Schüßler, A. (2016a). A conserved arbuscular mycorrhizal fungal core-species community colonizes potato roots in the Andes. Fungal Divers. 77, 317-333. doi: 10.1007/s13225-015-0328-7

Senés-Guerrero, C., and Schüßler, A. (2016b). "DNA-based characterization and identification of arbuscular mycorrhizal fungi species," in Microbial Environmental Genomics. Series: Methods in Molecular Biology, Vol. 1399, eds F. Uroz and S. Martin I (New York, NY: Springer), 101-123.

Senés-Guerrero, C., Torres-Cortés, G., Pfeiffer, S., Rojas, M., and Schüßler, A. (2014). Potato-associated arbuscular mycorrhizal fungal communities in the Peruvian Andes. Mycorrhiza 24, 405-417. doi: 10.1007/s00572-0130549-0 
Simard, S. W., and Austin, M. E. (2010). "The role of mycorrhizas in forest soil stability with climate change," in Climate Change and Variability, ed. S. Simard (Rijeka: InTechOpen), 275-301. doi: 10.5772/9813

Singh, H. (2006). "Mycoremediation: fungal bioremediation," in Mycoremediation: Fungal Bioremediation, ed. H. Singh (Hoboken, NJ: John Wiley \& Sons, Inc.).

Smith, S. E., and Read, D. (2008). Mycorrhizal Symbiosis, 3rd Edn. Cambridge: Academic Press.

Sonjak, S., Beguiristain, T., Leyval, C., and Regvar, M. (2009). Temporal temperature gradient gel electrophoresis (TTGE) analysis of arbuscular mycorrhizal fungi associated with selected plants from saline and metal polluted environments. Plant Soil 314, 25-34. doi: 10.1007/s11104-0089702-5

Souza, T. (2015). Handbook of Arbuscular Mycorrhizal Fungi. Berlin: Springer Science+Business Media. doi: 10.1007/978-3-319-24850-9

Stamatakis, A., Hoover, P., and Rougemont, J. (2008). A Rapid bootstrap algorithm for the RAxML web servers. Syst. Biol. 57, 758-771. doi: 10.1080/ 10635150802429642

Stockinger, H., Krüger, M., and Schüßler, A. (2010). DNA barcoding of arbuscular mycorrhizal fungi. New Phytol. 187, 461-474. doi: 10.1111/j.1469-8137.2010. 03262.x

Stürmer, S. L., and Siqueira, J. O. (2011). Species richness and spore abundance of arbuscular mycorrhizal fungi across distinct land uses in Western Brazilian Amazon. Mycorrhiza 21, 255-267. doi: 10.1007/s00572-010-0330-6

Trufem, S. F. B. (1990). Aspectos ecológicos de fungos micorrízicos vesículoarbusculares da mata tropical úmida da ilha do cardoso, SP, Brasil. Acta Bot. Bras. 4, 31-45. doi: 10.1590/S0102-33061990000200003

Vallino, M., Massa, N., Lumini, E., Bianciotto, V., Berta, G., and Bonfante, P. (2006). Assessment of arbuscular mycorrhizal fungal diversity in roots of Solidago gigantea growing in a polluted soil in Northern Italy. Environ. Microbiol. 8, 971-983. doi: 10.1111/j.1462-2920.2006.00980.x
Villacrés, B. H., Medina, M., Cumbal, L., and Villarroel, A. (2014). Implementación de un banco de Hongos Micorrícicos Arbusculares, aislados de suelos del área de influencia de EP PETROCUADOR y su efecto en el desarrollo de plantas de Maíz (Zea mays) en condiciones de estrés por cadmio, en La Joya de los Sachas, Provin. Congr. Cienc. Technol. 9, 24-35.

Walker, C. (2005). A simple blue staining technique for arbuscular mycorrhizal and other root-inhabiting fungi. Inoculum 56, 68-69.

Wang, B., and Qiu, Y. L. (2006). Phylogenetic distribution and evolution of mycorrhizas in land plants. Mycorrhiza 16, 299-363. doi: 10.1007/s00572-0050033-6

Wang, Y., Li, Y., Bao, X., Björn, L. O., Li, S., and Olsson, P. A. (2016). Response differences of arbuscular mycorrhizal fungi communities in the roots of an aquatic and a semiaquatic species to various flooding regimes. Plant Soil 403, 361-373. doi: 10.1007/s11104-016-2811-7

Wei, Y., Chen, Z., Wu, F., Li, J., ShangGuan, Y., Li, F., et al. (2015). Diversity of arbuscular mycorrhizal fungi associated with a sb accumulator plant, ramie (Boehmeria nivea), in an active Sb mining. Microbiol. Biotechnol. 25, 1205-1215. doi: $10.4014 /$ jmb.1411.11033

Conflict of Interest Statement: The authors declare that the research was conducted in the absence of any commercial or financial relationships that could be construed as a potential conflict of interest.

Copyright (C) 2017 Garcés-Ruiz, Senés-Guerrero, Declerck and Cranenbrouck. This is an open-access article distributed under the terms of the Creative Commons Attribution License (CC BY). The use, distribution or reproduction in other forums is permitted, provided the original author(s) or licensor are credited and that the original publication in this journal is cited, in accordance with accepted academic practice. No use, distribution or reproduction is permitted which does not comply with these terms. 